\title{
Extended storage of cold raw milk on yogurt manufacturing
}

\author{
Rafael Fagnani ${ }^{(1)}$, Josiane Schuck ${ }^{(1)}$, Bruno Garcia Botaro(2) and Fernando Cesar dos Santos ${ }^{(1)}$
}

(1)Universidade Norte do Paraná, Rua Marselha, no591, Jardim Piza, CEP 86041-120 Londrina, PR, Brazil. E-mail: rafaelfagnani@hotmail.com, josianeschuck@hotmail.com, fernandocesarsantos@gmail.com ${ }^{(2)}$ Animal \& Grassland Research and Innovation Centre, Teagasc Moorepark, Fermoy, Co. Cork, Ireland. E-mail: botarobruno@gmail.com

\begin{abstract}
The objective of this work was to evaluate the effect of the extended cold storage of raw milk on the kinetics of fermentation on yogurt production, as well as on the product's microbiological and physicochemical properties during shelf life. Three treatments were evaluated: yogurts made with raw milk stored for 4, 72, and 168 hours. Kinetics of fermentation was assessed through the lactic acid production rate, growth rate of Streptococcus thermophilus and Lactobacillus bulgaricus, and time to reach pH 5.0 and 4.5. The physicochemical and microbiological characteristics of raw milk and yogurts were also analyzed during cold storage at $4{ }^{\circ} \mathrm{C}$. The microbial quality of raw milk was affected by the storage time of 168 hours, with a decreasing tendency in the mesophiles:psychrotrophs ratio. Extended storage of raw milk beyond 72 hours negatively affects yogurt production, despite the low initial bacterial count, decreasing lactic acid production, S. thermophilus growth rate, $\mathrm{pH}$, and protein content. Therefore, to optimize fermentation and yogurt shelf life, the maximum storage time for raw milk at $4^{\circ} \mathrm{C}$ should not exceed 72 hours.
\end{abstract}

Index terms: Lactobacillus bulgaricus, Streptococcus thermophilus, fermentation, kinetics, psychrotrophs.

\section{Armazenamento prolongado de leite cru refrigerado sobre a produção de iogurte}

\begin{abstract}
Resumo - O objetivo deste trabalho foi avaliar o efeito do armazenamento prolongado de leite cru refrigerado na cinética de fermentação na produção de iogurte, bem como nas características físico-químicas e microbiológicas do produto durante sua vida útil. Três tratamentos foram avaliados: iogurte feito com leite cru armazenado por 4, 72 e 168 horas. A cinética de fermentação foi analisada por meio da taxa de produção de ácido lático, da velocidade de crescimento de Streptococcus thermophilus e Lactobacillus bulgaricus, e do tempo até atingir pH 5,0 e 4,5. As características físico-químicas e microbiológicas do leite cru e do iogurte também foram avaliadas durante o armazenamento refrigerado a $4^{\circ} \mathrm{C}$. A qualidade microbiológica do leite cru foi influenciada pelo tempo de armazenamento de 168 horas, com tendência de decréscimo na proporção mesófilos:psicrotróficos. O armazenamento prolongado do leite cru acima de 72 horas influencia negativamente a produção de iogurte, mesmo com contagem bacteriana inicial baixa, com diminuição na taxa de produção de ácido lático, na velocidade de crescimento de $S$. thermophilus, no $\mathrm{pH}$ e na percentagem de proteína. Portanto, para otimização da fermentação e da vida útil do iogurte, o tempo de armazenamento do leite cru a $4^{\circ} \mathrm{C}$ não deve exceder 72 horas.
\end{abstract}

Termos para indexação: Lactobacillus bulgaricus, Streptococcus thermophilus, fermentação, cinética, psicrotróficos.

\section{Introduction}

Milk cooling in dairy farms and the bulk hauling system are common practices within the dairy production chain of many countries to maintain the microbiological quality of raw milk until arrival at the industry. However, the heat-resistant enzymes involved in the growth of psychrotrophic bacteria severely affect the quality of dairy products such as yogurts and other fermented milks (Decimo et al., 2014).
Even though some topics on spoilage microorganisms have been extensively explored, including Pseudomonas spp. and their proteolytic potential (Scatamburlo et al., 2015), only a few studies have investigated the maximum cold storage time of raw material to prevent industrial losses. It has been reported that raw milk with high bacterial counts, especially of psychrotrophic microorganisms, may impair the production and yield of yogurts, reducing the products' shelf life and acceptance (Al-Kadamany 
et al., 2003; Shin et al., 2014). However, there is no knowledge of studies, at a dairy plant level, that clearly indicate how cold storage of raw milk could diminish losses due to psychrotrophic bacteria growth.

During the past 30 years, many researchers have studied the effects of cold storage conditions on the microbiological and physicochemical characteristics of milk, but only some have considered the effect of cold storage on the processing properties of dairy products. It was observed that the cold storage of raw milk results in casein dissociation, in the release of inorganic calcium from the micelles, and in the increased activities of plasmins and associated enzymes, i.e., proteases and lipases, affecting shelf life and ultimately the quality of heat-processed dairy products (Malacarne et al., 2013). Furthermore, the cleavage of the fat globule membrane by phospholipases to glycerol and fatty acids leads to milk fat degradation (Lopez et al., 2010). It should be noted, however, that these studies are mainly focused on cheese yield, not on how raw milk storage can affect the quality of processed yogurts related to fermentation and shelf life (Leitner et al., 2008).

Besides low yield, microbiological contamination of raw milk can also result in sensory defects and reduced shelf life. Çakmakçi et al. (2012) observed satisfactory sensory scores for freshly made yogurts, which, however, decreased after seven days of storage, resulting in higher acidity, which is less preferred by the consumer.

Therefore, since psychrotrophic microbiota of milk may negatively affect yogurt production and decrease shelf life, further studies on their effect on dairy products can help industries reduce losses and optimize the fermentation process.

The objective of this work was to evaluate the effect of the extended cold storage of raw milk on the kinetics of fermentation on yogurt production, as well as on the product's microbiological and physicochemical characteristics during shelf life.

\section{Materials and Methods}

The raw milk used throughout the experiment was obtained from one farm with enclosed milking facilities and a plate precooler, selected as it complied with wellestablished criterion for quality raw milk production: good milking and herd management practices; and low somatic cell and total bacterial counts at a bulk tank level.

After milking and cooling at $4{ }^{\circ} \mathrm{C}, 5 \mathrm{~L}$ of milk from the farm tank were aseptically collected and immediately hauled, at $4^{\circ} \mathrm{C}$, to the dairy pilot plant of Universidade do Norte do Paraná. Raw milk was kept refrigerated at $4^{\circ} \mathrm{C}$ throughout the entire evaluation period for 4,72 , and 168 hours before being pasteurized at $62^{\circ} \mathrm{C}$, for $30 \mathrm{~min}$, and processed to yogurt. Therefore, the yogurt was manufactured with the same milk batch, which was subjected to different storage times, resulting in three treatments: yogurts produced from raw milk kept for 4 (D0), 72 (D3), and 168 hours (D7) at $4^{\circ} \mathrm{C}$.

Raw milk was analyzed at D0, D3, and D7 for: physicochemical characteristics, which included $\mathrm{pH}$, titratable acidity, total protein, fat, lactose, total solids, and ash content; and microbiological characteristics, in this case, the enumeration of aerobic mesophilic microorganisms, psychrotrophs, coliforms, and Escherichia coli.

At D0, milk somatic cell count, using the Somacount 300 instrument (Bentley Instruments, Inc., Chaska, MN, USA), and antibiotic residue analysis, with the Snap Beta-Lactam ST and Snap Duo Beta-Tetra tests (Idexx Laboratories, Inc., Westbrook, ME, USA), were also assessed.

$\mathrm{pH}$ was measured by a potentiometer and acidity by titration with Dornic solution (0.1111 N NaOH), using phenolphthalein as the indicator. Nitrogen content was estimated by the micro-Kjeldahl method followed by conversion $(\times 6.38)$ to crude protein content (Wehr \& Frank, 2004), whereas Gerber's method was used to estimate fat content (Wehr \& Frank, 2004). Total solids were measured by oven drying at $105^{\circ} \mathrm{C}$ for 16 hours, and ash was determined according to Wehr \& Frank (2004).

A Petrifilm AC plate (3M Company, St. Paul, MN, USA) was used to enumerate aerobic mesophilic flora at $37^{\circ} \mathrm{C}$ for 48 hours. Psychrotrophic microorganisms were enumerated by surface plating of the milk sample onto plate count agar (PCA) medium at $21^{\circ} \mathrm{C}$ for 25 hours. A Petrifilm EC plate (3M Company, St. Paul, $\mathrm{MN}, \mathrm{USA}$ ) was used to enumerate total coliforms and E. coli, respectively, at $37^{\circ} \mathrm{C}$ for 24 hours and at $37^{\circ} \mathrm{C}$ for 48 hours. The Petrifilm system was used according to the manufacturer's instructions.

For yogurt manufacturing, pasteurized milk at $62^{\circ} \mathrm{C}$ was cooled to $42^{\circ} \mathrm{C}$ and promptly inoculated 
with a Streptococcus thermophilus and Lactobacillus bulgaricus lyophilized yogurt culture (FD-DVS YF L812 Yo-Flex, Chr. Hansen Holding A/S, Hoersholm, Denmark) at $1 \%(\mathrm{wt} / \mathrm{wt})$. Subsequently, inoculated milk was poured into $1,000-\mathrm{mL}$ sterile glass bottles and into $18-\mathrm{cm}$ sterile screw-cap test tubes, then incubated at $45^{\circ} \mathrm{C}$.

$\mathrm{pH}$ was monitored during milk renneting until $\mathrm{pH} 4.5$ (pH end point); the milk was then cooled at $4^{\circ} \mathrm{C}$ and kept stored until further analysis.

Kinetics of fermentation from each batch was determined by placing 10 to $20 \mathrm{~mL}$ of each freshly inoculated yogurt (D0, D3, and D7) in 20 sterile test tubes, kept incubated at $43^{\circ} \mathrm{C}$. Two tubes (duplicate) at a time were taken every $30 \mathrm{~min}$ for $\mathrm{pH}$ and Dornic acidity determination. Another aliquot was used for the microbiological analysis, which was assessed once every subsequent hour.

For further physicochemical analysis and storage effect evaluation, $300 \mathrm{~mL}$ of each freshly inoculated yogurt (D0, D3, and D7) were packed into three sterile screw-cap glass containers.

To assess fermentation kinetics (20 tubes) throughout the fermentation process, an aliquot was analyzed as to: lactic acid production rate, in $\mathrm{g} \mathrm{L}^{-1} \mathrm{~h}^{-1}$; growth rate of $S$. thermophilus and L. bulgaricus, in colonyforming unit (CFU) $\mathrm{L}^{-1} \mathrm{~h}^{-1}$; and time to $\mathrm{pH} 5.0$ and to 4.5 in minutes, which was evaluated every $30 \mathrm{~min}$.

To calculate the lactic acid production rate, at 30-min intervals, two tubes were retrieved from incubation for $\mathrm{pH}$ and titratable acidity (in duplicate) determination, in order to plot the fermentation curve, as follows: $\mathrm{dP} / \mathrm{dt}=\left[\left(\ln \mathrm{P}_{3}-\ln \mathrm{P}_{1}\right) /\left(\mathrm{t}_{3}-\mathrm{t}_{1}\right)\right] \times \mathrm{P}_{2}$, in which $\ln$ is the Naperian logarithm; $P$ is the lactic acid concentration $\left(\mathrm{g} \mathrm{L}^{-1}\right) ; \mathrm{P}_{1}$ is the lactic acid concentration at time $\mathrm{t}_{1} ; \mathrm{P}_{2}$ is the lactic acid concentration at time $\mathrm{t}_{2} ; \mathrm{P}_{3}$ is the lactic acid concentration at time $\mathrm{t}_{3}$; and $\mathrm{t}$ is the fermentation time (Sinclair \& Cantero, 1990).

To determine the growth rate of $S$. thermophilus and L. bulgaricus, at every hour of fermentation, one test tube was removed from the incubation chamber to enumerate $S$. thermophilus and L. bulgaricus populations in duplicate analysis. For L. bulgaricus, this was done by plate count with de Man-RogosaSharpe (MRS) agar, with the addition of acetic acid, at $\mathrm{pH} 5.4$, incubated anaerobically at $37^{\circ} \mathrm{C}$ for 72 hours; and, for $S$. thermophilus, with lactose-M17 agar aerobically incubated at $37^{\circ} \mathrm{C}$ for 48 hours (Wehr
\& Frank, 2004). The following formula was used: $\mathrm{dP} / \mathrm{dt}=\left[\left(\ln \mathrm{X}_{3}-\ln \mathrm{X}_{1}\right) /\left(\mathrm{t}_{3}-\mathrm{t}_{1}\right)\right] \times \mathrm{X}_{2}$, in which $\ln$ is the Naperian logarithm; $X_{1}$ is the population of microorganisms at time $t_{1} ; X_{2}$ is the population of microorganisms at time $t_{2} ; X_{3}$ is the population of microorganisms at time $t_{3}$; and $t$ is the fermentation time (Sinclair \& Cantero, 1990).

For determination of the physicochemical and microbiological properties of the yogurts during shelf life, three yogurt samples of each treatment (D0, D3, and D7) were stored at $4^{\circ} \mathrm{C}$ and evaluated at 24 hours, 7 days, and 15 days after manufactured. Titratable acidity, $\mathrm{pH}$, total protein, fat, lactose, total solids, ash, as well as L. bulgaricus, S. thermophilus, yeast, mold, total coliforms and E. coli counts, were determined as previously described. A Petrifilm YM plate (3M Company, St. Paul, MN, USA) was used to enumerate yeasts and molds at $24^{\circ} \mathrm{C}$ for 72 hours.

Data were subjected to the Kolmogorov-Smirnov test, and visual inspection of the distribution was used to check normality and homoscedasticity (Drezner et al., 2010). Normal distribution was not observed and, therefore, the numerical variables (enumeration of aerobic mesophiles, psychrotrophs, and coliforms) were categorized as ordinal scale by logarithmic transformation.

Observed differences in the microbiological enumeration and physicochemical characteristics of raw milk and yogurts during storage were assessed by the Wilcoxon paired test, at $5 \%$ probability. The variables of each treatment were also compared in pairs using the same statistical approach, and the experiment was performed fivefold to account for randomized effects.

\section{Results and Discussion}

A decrease in aerobic mesophilic bacteria was observed when compared with the initial counts in raw milk after 168 hours of storage at $4^{\circ} \mathrm{C}$, from 4.38 to $4.05 \log$ CFU mL $\mathrm{m}^{-1}$, respectively (Table 1). However, the number of psychrotrophic bacteria remained the same throughout the seven-day storage period.

The mesophiles:psychrotrophs ratio also decreased during raw milk storage. Although from D0 to D3, the average ratio remained unchanged, there was a decrease to 0.88 at D7. In the present study, a trend for the reduction of the aerobic mesophilic population 
was observed during the cold storage of raw milk (Table 1). This pattern is related to the adaptation of microorganisms to refrigeration (Souza et al., 2009) and has also been reported by Malacarne et al. (2013) and O'Connell et al. (2016). For most psychrotrophs, optimum growth temperatures range from 20 to $30^{\circ} \mathrm{C}$, since these are primarily mesophilic microorganisms capable of adapting to milk cooling temperatures. In addition, psychrotrophic microbiota selection occurs at around $4{ }^{\circ} \mathrm{C}$, producing heat-resistant enzymes and, consequently, increasing rancidity and bitter taste, besides decreasing dairy product yield (Stoeckel et al., 2016)

In the European Union and the United States, milk quality regulations standardized total bacterial count for dairy manufacturing at $\leq 100,000 \mathrm{CFU} \mathrm{mL}^{-1}$ (European Comission, 2004; Grade..., 2011). However, current Brazilian ordinance limits total bacterial count in raw milk to $300,000 \mathrm{CFU} \mathrm{mL}^{-1}$ (Brasil, 2011). Therefore, all batches of raw milk used in the present study complied with the Brazilian statutory regulation.

Total coliforms and E. coli in raw milk remained unchanged during the entire storage period (Table 1). Coliforms ranged from 1 to $3.56 \log \mathrm{CFU} \mathrm{mL} \mathrm{mL}^{-1}$, whereas $E$. coli ranged from $<1$ to $10 \mathrm{CFU} \mathrm{mL}^{-1}$. Since trading of raw milk for direct consumption in Brazil is forbidden, neither coliforms nor E. coli $\mathrm{CFU}$ limits are established in the country's milk ordinance.

No differences were found for raw milk physicochemical parameters at $4{ }^{\circ} \mathrm{C}$ during the storage period (Table 1). Titratable acidity, $\mathrm{pH}$, fat, and protein content remained constant during the seven days of storage. Owing to the low CFU initially observed in the raw milk and to its storage temperature, only minor changes on those parameters were observed due to bacterial spoilage (psychrotrophs). However, expected changes in further physicochemical properties, such as water-soluble nitrogen, nonprotein nitrogen, peptide nitrogen, free amino acids with the production of heat-stable proteases and lipases, would be likely to occur with time (Mankai et al., 2012). These latter parameters, however, were beyond the scope of the present study and, therefore, were not assessed.

The lactic acid production rate during fermentation was affected by the increase of raw milk storage time (Table 2). Even though no differences were observed between yogurts produced from raw milk stored for 4 and 72 hours, there was a decrease in the rate of lactic acid production with storage for 168 hours.

The growth rate of $S$. thermophilus was also affected by raw milk storage (Table 2). The bacteria showed limited activity due to the storage time lapse,

Table 1. Median, mean $(\overline{\mathrm{X}})$, standard deviation $(\sigma)$, and range $(\mathrm{H})$ of $\mathrm{pH}$, titratable acidity, fat, total protein, aerobic mesophilic bacteria (Am) and psychrotrophic bacteria (Psy) counts, aerobic mesophiles:psychrotrophs ratio (Am:Psy), and total coliform and Escherichia coli $(\mathrm{Ec})$ counts in raw milk stored for 4 (D0), 72 (D3), and 168 (D7) hours at $4^{\circ} \mathrm{C}^{(1)}$.

\begin{tabular}{|c|c|c|c|c|c|c|}
\hline \multirow{2}{*}{$\begin{array}{l}\text { Physicochemical and microbiological } \\
\text { characteristics }\end{array}$} & \multicolumn{2}{|c|}{ D0 } & \multicolumn{2}{|c|}{ D3 } & \multicolumn{2}{|c|}{ D7 } \\
\hline & Median & $\overline{\mathrm{X}} \pm \sigma$ & Median & $\overline{\mathrm{X}} \pm \sigma$ & Median & $\overline{\mathrm{X}} \pm \sigma$ \\
\hline $\mathrm{pH}$ & 6.70 & $\begin{array}{l}6.69 \pm 0.03 \\
6.64 \mathrm{H} 6.72\end{array}$ & 6.79 & $\begin{array}{l}6.75 \pm 0.10 \\
6.62 \mathrm{H} 6.84\end{array}$ & 6.68 & $\begin{array}{l}6.71 \pm 0.08 \\
6.63 \mathrm{H} 6.83\end{array}$ \\
\hline Titratable acidity $\left({ }^{\circ} \mathrm{D}\right)$ & 16.30 & $\begin{array}{c}16.68 \pm 2.01 \\
14.0 \mathrm{H} 20.0\end{array}$ & 16.30 & $\begin{array}{c}16.36 \pm 0.74 \\
15.0 \mathrm{H} 18.0 \\
\end{array}$ & 16.00 & $\begin{array}{c}16.36 \pm 0.96 \\
15.0 \mathrm{H} 18.0 \\
\end{array}$ \\
\hline Fat $(\%)$ & 3.40 & $\begin{array}{l}3.52 \pm 0.39 \\
3.20 \mathrm{H} 4.10\end{array}$ & 3.45 & $\begin{array}{l}3.40 \pm 0.29 \\
3.00 \mathrm{H} 3.70\end{array}$ & 3.40 & $\begin{array}{l}3.38 \pm 0.15 \\
3.20 \mathrm{H} 3.60\end{array}$ \\
\hline Total protein $(\%)$ & 3.15 & $\begin{array}{l}3.13 \pm 0.20 \\
2.90 \mathrm{H} 3.32\end{array}$ & 3.49 & $\begin{array}{l}3.45 \pm 0.38 \\
3.03 \mathrm{H} 3.79 \\
\end{array}$ & 3.38 & $\begin{array}{l}3.26 \pm 0.30 \\
2.86 \mathrm{H} 3.54 \\
\end{array}$ \\
\hline $\begin{array}{l}\text { Aerobic mesophilic bacteria } \\
\left(\log \mathrm{CFU} \mathrm{mL} \mathrm{mL}^{-1}\right)\end{array}$ & $4.38 \mathrm{a}$ & $\begin{array}{l}4.32 \pm 0.22 \\
4.10 \mathrm{H} 4.63 \\
\end{array}$ & $4.34 \mathrm{a}$ & $\begin{array}{l}4.34 \pm 0.24 \\
4.11 \mathrm{H} 4.65 \\
\end{array}$ & $4.05 b$ & $\begin{array}{l}4.17 \pm 0.26 \\
3.89 \mathrm{H} 4.57 \\
\end{array}$ \\
\hline $\begin{array}{l}\text { Psychrotrophic bacteria counts } \\
\left(\log \mathrm{CFU} \mathrm{mL} \mathrm{mL}^{-1}\right)\end{array}$ & 4.67 & $\begin{array}{l}4.57 \pm 0.25 \\
4.18 \mathrm{H} 4.86 \\
\end{array}$ & 4.74 & $\begin{array}{l}4.65 \pm 0.34 \\
4.19+4.92 \\
\end{array}$ & 4.69 & $\begin{array}{l}4.73 \pm 0.19 \\
4.51 \mathrm{H} 5.01 \\
\end{array}$ \\
\hline Am:Psy ratio & $0.94 b$ & $\begin{array}{l}0.95 \pm 0.06 \\
0.88 \mathrm{H} 1.03\end{array}$ & $0.92 b$ & $\begin{array}{l}0,93 \pm 0.05 \\
0.88 \mathrm{H} 0.98\end{array}$ & $0.89 \mathrm{a}$ & $\begin{array}{l}0.88 \pm 0.03 \\
0.84 \mathrm{H} 0.91\end{array}$ \\
\hline $\begin{array}{l}\text { Total coliform } \\
\left(\log \mathrm{CFU} \mathrm{mL} \mathrm{mL}^{-1}\right)\end{array}$ & 1.78 & $\begin{array}{l}2.09 \pm 0.94 \\
1.30 \mathrm{H} 3.50\end{array}$ & 1.90 & $\begin{array}{l}2.15 \pm 0.79 \\
1.70 \mathrm{H} 3.56\end{array}$ & 1.15 & $\begin{array}{l}1.74 \pm 1.05 \\
1.00 \mathrm{H} 3.43\end{array}$ \\
\hline 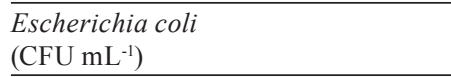 & 3.00 & $\begin{array}{c}4.20 \pm 3.35 \\
2.00 \mathrm{H} 10.00\end{array}$ & 1.00 & $\begin{array}{l}2.20 \pm 2.17 \\
<1.0 \mathrm{H} 5.00\end{array}$ & 1.00 & $\begin{array}{l}3.00 \pm 4.06 \\
<1.0 \mathrm{H} 10.0 \\
\end{array}$ \\
\hline
\end{tabular}

${ }^{(1)}$ Medians followed by different letters, lowercase in the lines, differ by Wilcoxon's test, at $5 \%$ probability. 
causing the decrease in lactic acid yield, which was probably related to the storage of milk prior to its pasteurization, when free fatty acids might have been released by psychrotrophic enzymes, inhibiting the growth of lactic acid bacteria (Beal et al., 2001; Huang et al., 2010). Polyunsaturated fatty acids, such as free linoleic acid and oleic acid, are reported to lead S. thermophilus, Lactobacillus GG (probiotic), and Lactobacillus casei Shirota to cell death (Kankaanpää et al., 2001). This is important since the acidifying ability of $S$. thermophilus decreases yogurt $\mathrm{pH}$ (Lecomte et al., 2016).

The fermentation time span among D0, D3, and D7 yogurts did not differ. The time lapse to $\mathrm{pH} 5.0$ was of 3 hours and to the final $\mathrm{pH} 4.5$ of 4.2 hours, with an average time span of 2.2 hours to reach the highest lactic acid production (Figure 1). Oliveira et al. (2009) investigated milk fermentation using $S$. thermophilus and L. bulgaricus and found an average time lapse of 3.68 hours to $\mathrm{pH} 5.0$, of 5.47 hours to the final $\mathrm{pH} 4.5$, and of 3 hours to the highest acidification rate.

Viable cell counts of $S$. thermophilus and $L$. bulgaricus increased during the fermentation process in all treatments. However, S. thermophilus counts (7 to $8 \log \mathrm{CFU} \mathrm{mL}^{-1}$ ) remained higher than those of
L. bulgaricus ( 2 to $3 \log \mathrm{CFU} \mathrm{mL}^{-1}$ ) throughout the entire fermentation process (Figure 2). A ratio of 5:1 (chain:chain) of $S$. thermophilus to L. bulgaricus is desired in yogurt and can be achieved at an optimum $\mathrm{pH}$ of 6.4 and temperature of $46^{\circ} \mathrm{C}$ (Aghababaie et al., 2015).

It was also observed that the storage time span of raw milk negatively affected the $\mathrm{pH}$ of the produced yogurts during shelf life (Table 3), decreasing the $\mathrm{pH}$ median from 4.41, on the first day of storage, to 3.93 after 15 days of storage. However, this difference was solely observed for the D7 yogurt, which leads to the assumption that, regardless of its initial bacterial count, the manufacturing viability of aged raw milk to yogurt can be reduced, as found in the present study.

The decrease in $\mathrm{pH}$ leads to a substantial sour taste in yogurt. Although sourness is an expected characteristic of yogurt, excessive acidification (post-acidification) may result in lower acceptance, syneresis, and variations in aroma volatile metabolites, especially in acetic acid and 2-butanone, as well as in nonvolatile ones, decreasing the organoleptic quality of yogurt (Çakmakçi et al., 2012; Settachaimongkon et al., 2016).

Table 2. Median, mean $(\overline{\mathrm{X}})$, standard deviation $(\sigma)$, and range $(\mathrm{H})$ of lactic acid production rate (L.acid), growth rate of Streptococcus thermophilus $(\mathrm{St})$ and Lactobacillus bulgaricus $(\mathrm{Lb})$, time lapse to $\mathrm{pH} 5.0\left(\mathrm{t}_{\mathrm{pH}}\right.$ 5.0) and to $\mathrm{pH} 4.5\left(\mathrm{t}_{\mathrm{pH}} 4.5\right)$, time lapse to the highest lactic acid production rate (Tmax L.acid), and time lapse to the highest growth rate of S. thermophilus (Tmax St) and L. bulgaricus (Tmax Lb) in yogurts produced from raw milk stored for 4 (D0), 72 (D3), and 168 (D7) hours at $4^{\circ} \mathrm{C}^{(1)}$.

\begin{tabular}{|c|c|c|c|c|c|c|}
\hline \multirow{2}{*}{$\begin{array}{l}\text { Physicochemical and microbiological } \\
\text { characteristics }\end{array}$} & \multicolumn{2}{|c|}{ D0 } & \multicolumn{2}{|c|}{ D3 } & \multicolumn{2}{|c|}{ D7 } \\
\hline & Median & $\overline{\mathrm{X}} \pm \sigma$ & Median & $\overline{\mathrm{X}} \pm \sigma$ & Median & $\overline{\mathrm{X}} \pm \sigma$ \\
\hline \multirow{2}{*}{$\begin{array}{l}\text { L.acid } \\
\left(\mathrm{g} \mathrm{L}^{-1} \mathrm{~h}^{-1}\right)\end{array}$} & \multirow{2}{*}{$1.89 \mathrm{a}$} & $1.70 \pm 0.69$ & \multirow{2}{*}{$2.02 \mathrm{a}$} & $1.84 \pm 0.73$ & \multirow{2}{*}{$1.73 b$} & $1.62 \pm 0.68$ \\
\hline & & $0.13 \mathrm{H} 2.83$ & & $0.14 \mathrm{H} 3.26$ & & $0.13 \mathrm{H} 3.60$ \\
\hline \multirow{2}{*}{$\begin{array}{l}\text { St } \\
\left(\log \mathrm{CFU} \mathrm{L}^{-1} \mathrm{~h}^{-1}\right)\end{array}$} & \multirow{2}{*}{$8.92 \mathrm{ab}$} & $8.88 \pm 0.27$ & \multirow{2}{*}{$9.00 \mathrm{a}$} & $9.07 \pm 0.21$ & \multirow{2}{*}{$8.84 b$} & $8.83 \pm 0.14$ \\
\hline & & $8.28+9.10$ & & $8.86 \mathrm{H} 9.44$ & & $8.54 \mathrm{H} 8.97$ \\
\hline $\mathrm{Lb}$ & \multirow{2}{*}{1.95} & $1.93 \pm 0.37$ & \multirow{2}{*}{2.18} & $2.22 \pm 0.39$ & \multirow{2}{*}{2.25} & $2.18 \pm 0.53$ \\
\hline$\left(\log \mathrm{CFU} \mathrm{L}^{-1} \mathrm{~h}^{-1}\right)$ & & $1.37 \mathrm{H} 2.41$ & & $1.78 \mathrm{H} 2.79$ & & $1.28 \mathrm{~F} 2.79$ \\
\hline \multirow{2}{*}{$\begin{array}{l}\mathrm{t}_{\mathrm{pH} 5.0} \\
(\mathrm{~min})\end{array}$} & \multirow{2}{*}{186} & $180 \pm 23.66$ & \multirow{2}{*}{186} & $180 \pm 23.66$ & \multirow{2}{*}{174} & $180 \pm 12.65$ \\
\hline & & $150 \mathrm{H} 210$ & & $150 \mathrm{H} 210$ & & $150 \mathrm{H} 180$ \\
\hline \multirow{2}{*}{$\begin{array}{l}\mathrm{t}_{\mathrm{pH} 4.5} \\
(\mathrm{~min})\end{array}$} & \multirow{2}{*}{258} & $240 \pm 25.30$ & \multirow{2}{*}{270} & $252 \pm 25.30$ & \multirow{2}{*}{240} & $240 \pm 28.28$ \\
\hline & & $240 \mathrm{H} 300$ & & $210 \mathrm{H} 270$ & & $210 \mathrm{H} 270$ \\
\hline \multirow{2}{*}{$\begin{array}{l}\text { Tmax L.acid } \\
\text { (min) }\end{array}$} & \multirow{2}{*}{150} & $144 \pm 12.65$ & \multirow{2}{*}{120} & $138 \pm 25.30$ & \multirow{2}{*}{120} & $126 \pm 12.65$ \\
\hline & & $120 \mathrm{H} 150$ & & $120 \mathrm{H} 180$ & & $120 \mathrm{H} 150$ \\
\hline \multirow{2}{*}{$\begin{array}{l}\text { Tmax St } \\
(\min )\end{array}$} & \multirow{2}{*}{180} & $165 \pm 27.78$ & \multirow{2}{*}{150} & $150 \pm 32.01$ & \multirow{2}{*}{120} & $135 \pm 27.78$ \\
\hline & & $120 \mathrm{H} 180$ & & $120 \mathrm{H} 180$ & & $120 \mathrm{H} 180$ \\
\hline \multirow{2}{*}{$\begin{array}{l}\mathrm{Tmax} \mathrm{Lb} \\
(\min )\end{array}$} & \multirow{2}{*}{180} & $160 \pm 30.98$ & \multirow{2}{*}{180} & $180 \pm 0.00$ & \multirow{2}{*}{180} & $180 \pm 0.00$ \\
\hline & & $120 \mathrm{H} 180$ & & $180 \mathrm{H} 180$ & & $180 \mathrm{H} 180$ \\
\hline
\end{tabular}

(1)Medians followed by different letters, lowercase in the lines, differ by Wilcoxon's test, at $5 \%$ probability. 

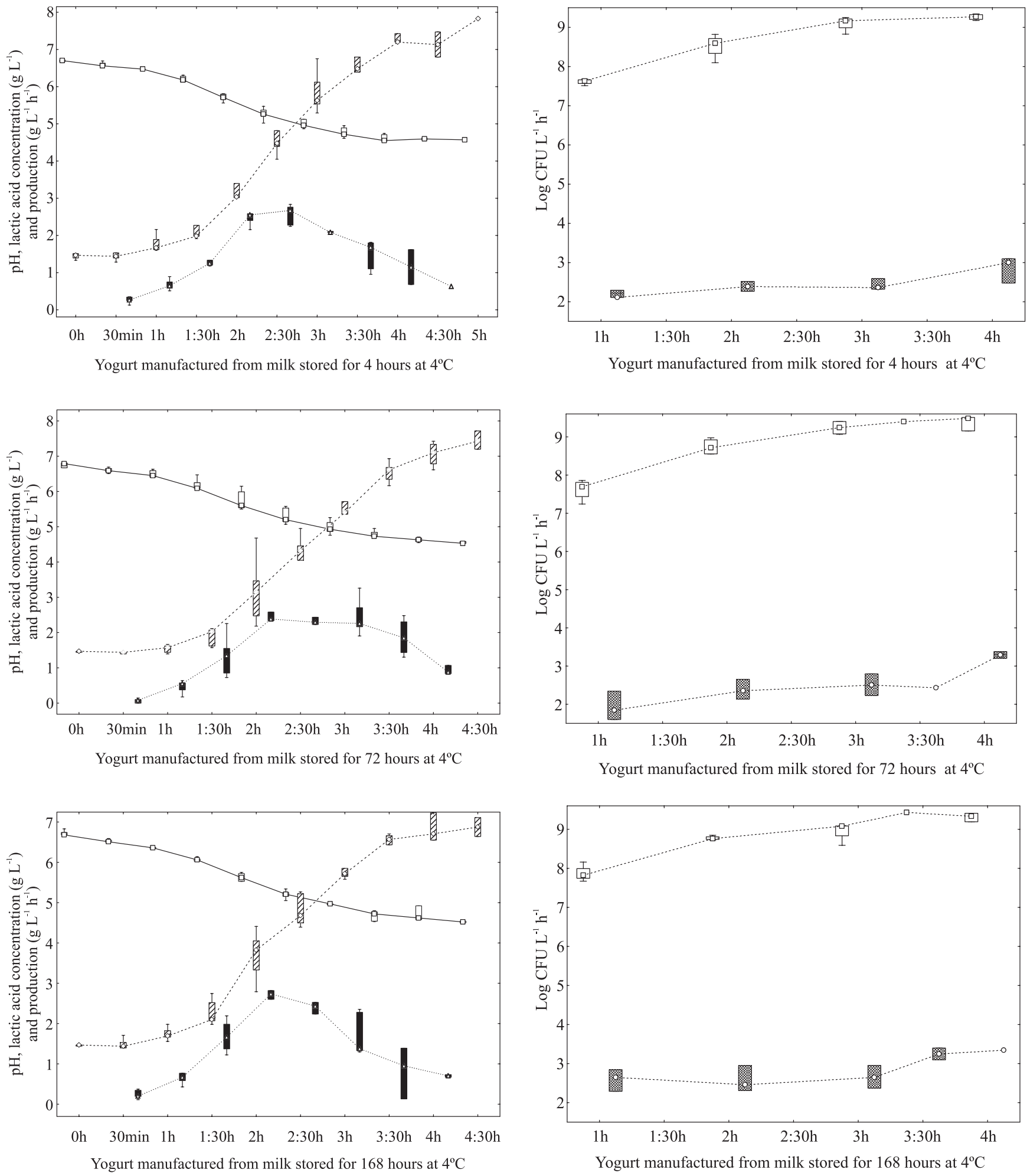

目 $\mathrm{pH}$ 因 Latic acid $\mathbf{\Delta}$ Latic acid production rate

回 Streptococcus thermophilus 0 Lactobacillus bulgaricus

Figure 1. pH, lactic acid concentration, and lactic acid production rate during fermentation of yogurts manufactured with raw milk stored for 4,72 , and 168 hours at $4^{\circ} \mathrm{C}$.

Figure 2. Streptococcus thermophilus and Lactobacillus bulgaricus populations in yogurts manufactured with raw milk stored for 4,72 , and 168 hours at $4^{\circ} \mathrm{C}$. 
The main reasons for post-acidification are the higher proportion of lactobacilli to streptococci and proteolysis (Rajapaksha et al., 2013). Since no changes were observed for the enumeration of $S$. thermophilus and L. bulgaricus in the present study, it is presumed that the protein degradation of the yogurt produced from raw milk stored for an extended period of time contributed to the acidification of the product.

The protein content of the yogurts stored for 15 days decreased when raw milk was stored for 72 and 168 hours (Table 3). Therefore, the extended storage of raw milk can affect the nutritional aspects of yogurt during shelf life, particularly when yogurt storage time must also be extended under refrigeration.

D7 raw milk produced the yogurt with the lowest protein content (Table 3). Yamazi et al. (2013) also reported low protein contents and decreased yield in cheese from raw goat milk kept refrigerated for more than 48 hours. According to Perin et al. (2012), when raw milk is stored at $4^{\circ} \mathrm{C}$, for an extended time period, the dairy product yield is reduced due to the growth of proteolytic psychrotrophic bacteria within 48 hours. As over $80 \%$ of the psychrotrophic microorganisms in raw milk may determine proteolysis, the remaining proteolytic activity must be considered even when milk is pasteurized or subjected to ultra-high temperature treatment prior to yogurt production (Nörnberg et al., 2010).

It should be highlighted that protein is not only regarded as an important nutrient, it also standardizes the identity of dairy products. For instance, protein percentages in fermented milks are required to be at least $2.9 \%$ in Brazil (Brasil, 2007). Consequently, raw milk storage can also play a key role in ensuring the availability of solids in raw milk, in order to comply with yogurt standards. Viable $S$. thermophilus and L. bulgaricus CFUs are also important for yogurt shelf life and identity. In the present study, the yogurt

Table 3. Median, mean $(\overline{\mathrm{X}})$, standard deviation $(\sigma)$, and range $(\mathrm{F})$ of $\mathrm{pH}$, titratable acidity, fat and total protein, as well as of Streptococcus thermophilus (St), Lactobacillus bulgaricus (Lb), total coliforms (Ct), Escherichia coli (Ec), and yeast and mold (Ym) counts, during shelf life of 1, 8, and 15 days of yogurts produced from raw milk stored for 4 (D0), 7 (D3), and 168 (D7) hours at $4^{\circ} \mathrm{C}^{(1)}$.

\begin{tabular}{|c|c|c|c|c|c|c|}
\hline \multirow{2}{*}{$\begin{array}{l}\text { Physicochemical and microbiological } \\
\text { characteristics }\end{array}$} & \multicolumn{2}{|c|}{1 day } & \multicolumn{2}{|c|}{8 days } & \multicolumn{2}{|c|}{15 days } \\
\hline & Median & $\overline{\mathrm{X}} \pm \sigma$ & Median & $\overline{\mathrm{X}} \pm \sigma$ & Median & $\overline{\mathrm{X}} \pm \sigma$ \\
\hline & \multicolumn{6}{|c|}{ D0, raw milk stored for 4 hours at $4^{\circ} \mathrm{C}$} \\
\hline pH & 4.35 & $4.38 \pm 0.08$ & 4.37 & $4.34 \pm 0.10$ & 4.33 & $4.25 \pm 0.18$ \\
\hline Titratable acidity $\left({ }^{\circ} \mathrm{D}\right)$ & 74.5 & $75.5 \pm 3.26$ & 76.3 & $75.5 \pm 1.53$ & 77.0 & $76.6 \pm 2.72$ \\
\hline Fat $(\%)$ & 3.10 & $3.16 \pm 0.13$ & 3.20 & $3.08 \pm 0.36$ & 3.30 & $3.10 \pm 0.57$ \\
\hline Total protein (\%) & 3.25 & $3.31 \pm 0.31$ & 3.64 & $3.56 \pm 0.19$ & $3.47 \mathrm{~A}$ & $3.42 \pm 0.25$ \\
\hline St $\left(\log C F U \mathrm{~mL}^{-1}\right)$ & 9.15 & $9.16 \pm 0.08$ & 9.10 & $9.12 \pm 0.07$ & 9.09 & $9.02 \pm 0.20$ \\
\hline $\mathrm{Lb}\left(\log \mathrm{CFU} \mathrm{mL}^{-1}\right)$ & 3.35 & $3.27 \pm 0.46$ & 3.53 & $3.58 \pm 0.13$ & 3.50 & $3.39 \pm 0.29$ \\
\hline \multirow[t]{2}{*}{$\mathrm{Ct} / \mathrm{Ec} / \mathrm{Ym}\left(\mathrm{CFU} \mathrm{mL}^{-1}\right)$} & $<1$ & $<1 \pm 0.00$ & $<1$ & $<1 \pm 0.00$ & $<1$ & $<1 \pm 0.00$ \\
\hline & \multicolumn{6}{|c|}{$\mathrm{D} 3$, raw milk stored for 7 hours at $4^{\circ} \mathrm{C}$} \\
\hline $\mathrm{pH}$ & 4.40 & $4.39 \pm 0.06$ & 4.38 & $4.36 \pm 0.10$ & 4.30 & $4.30 \pm 0.10$ \\
\hline Titratable acidity $\left({ }^{\circ} \mathrm{D}\right)$ & 75.5 & $76.1 \pm 2.75$ & 75.5 & $76.4 \pm 2.22$ & 76.8 & $77.3 \pm 1.53$ \\
\hline Fat $(\%)$ & 3.10 & $3.08 \pm 0.26$ & 2.90 & $2.86 \pm 0.40$ & 3.20 & $3.14 \pm 0.68$ \\
\hline Total protein (\%) & $3.41 \mathrm{ab}$ & $3.37 \pm 0.37$ & $3.53 \mathrm{a}$ & $3.72 \pm 0.55$ & $3.34 \mathrm{bA}$ & $3.14 \pm 0.47$ \\
\hline St $\left(\log C F U \mathrm{~mL}^{-1}\right)$ & 9.36 & $9.38 \pm 0.19$ & 9.18 & $9.17 \pm 0.16$ & 9.11 & $8.88 \pm 0.93$ \\
\hline $\mathrm{Lb}\left(\log \mathrm{CFU} \mathrm{mL}^{-1}\right)$ & 3.46 & $3.45 \pm 0.18$ & 3.64 & $3.52 \pm 0.32$ & 3.41 & $3.40 \pm 0.40$ \\
\hline \multirow[t]{2}{*}{$\mathrm{Ct} / \mathrm{Ec} / \mathrm{Ym}\left(\mathrm{CFU} \mathrm{mL} \mathrm{m}^{-1}\right)$} & $<1$ & $<1 \pm 0.00$ & $<1$ & $<1 \pm 0.00$ & $<1$ & $<1 \pm 0.00$ \\
\hline & \multicolumn{6}{|c|}{ D7, raw milk stored for 168 hours at $4^{\circ} \mathrm{C}$} \\
\hline $\mathrm{pH}$ & $4.41 \mathrm{a}$ & $4.38 \pm 0.16$ & $4.31 \mathrm{a}$ & $4.26 \pm 0.22$ & $3.93 b$ & $4.11 \pm 0.29$ \\
\hline Titratable acidity $\left({ }^{\circ} \mathrm{D}\right)$ & 77.0 & $77.0 \pm 4.51$ & 74.0 & $77.5 \pm 5.85$ & 77.3 & $77.3 \pm 3.62$ \\
\hline Fat $(\%)$ & 3.30 & $3.14 \pm 0.36$ & 3.30 & $3.28 \pm 0.16$ & 3.40 & $3.50 \pm 0.41$ \\
\hline Total protein $(\%)$ & 3.16 & $2.99 \pm 0.42$ & 3.20 & $3.24 \pm 0.34$ & $3.11 \mathrm{~B}$ & $3.09 \pm 0.29$ \\
\hline St $\left(\log C F U \mathrm{~mL}^{-1}\right)$ & 9.17 & $8.93 \pm 0.69$ & 9.24 & $8.82 \pm 0.87$ & 9.14 & $9.09 \pm 0.09$ \\
\hline $\mathrm{Lb}\left(\log \mathrm{CFU} \mathrm{mL} \mathrm{m}^{-1}\right)$ & 3.65 & $3.61 \pm 0.61$ & 3.37 & $3.40 \pm 0.15$ & 3.50 & $3.53 \pm 0.25$ \\
\hline $\mathrm{Ct} / \mathrm{Ec} / \mathrm{Ym}\left(\mathrm{CFU} \mathrm{mL}^{-1}\right)$ & $<1$ & $<1 \pm 0.00$ & $<1$ & $<1 \pm 0.00$ & $<1$ & $<1 \pm 0.00$ \\
\hline
\end{tabular}

${ }^{(1)}$ Medians followed by different letters, lowercase in the lines and uppercase in the columns, differ by Wilcoxon's test, at 5\% probability. 
bacterial counts within 15 days of storage were not different, regardless of which raw milk (D0, D3, or D7) was used (Table 3). It was observed that $S$. thermophilus and L. bulgaricus counts ranged from 9.09 to $9.36 \log \mathrm{CFU} \mathrm{mL} \mathrm{mL}^{-1}$ and from 3.35 to $3.65 \log$ CFU $\mathrm{mL}^{-1}$, respectively, which complied with the minimum lactic acid bacteria counts established for this product (Brasil, 2007).

\section{Conclusions}

1. The extended storage of raw milk at $4^{\circ} \mathrm{C}$ beyond 72 hours negatively affects yogurt manufacturing, regardless of the initial bacterial count, and decreases the lactic acid production rate and Streptococcus thermophilus growth rate during the fermentation process.

2. The extended storage of raw milk for more than 72 hours also affects yogurt shelf life by decreasing its $\mathrm{pH}$ and protein content.

\section{Acknowledgments}

To Coordenação de Aperfeiçoamento de Pessoal de Nível Superior (Capes), for financial support.

\section{References}

AGHABABAIE, M.; KHANAHMADI, M.; BEHESHTI, M. Developing a kinetic model for co-culture of yogurt starter bacteria growth in $\mathrm{pH}$ controlled batch fermentation. Journal of Food Engineering, v.166, p.72-79, 2015. DOI: 10.1016/j. jfoodeng.2015.05.013.

AL-KADAMANY, E.; KHATTAR, M.; HADDAD, T.; TOUFEILI, I. Estimation of shelf-life of concentrated yogurt by monitoring selected microbiological and physicochemical changes during storage. LWT - Food Science and Technology, v.36, p.407-414, 2003. DOI: 10.1016/S0023-6438(03)00018-5.

BEAL, C.; FONSECA, F.; CORRIEU, G. Resistance to freezing and frozen storage of Streptococcus thermophilus is related to membrane fatty acid composition. Journal of Dairy Science, v.84, p.2347-2356, 2001. DOI: 10.3168/JDS.S0022-0302(01)74683-8.

BRASIL. Ministério da Agricultura, Pecuária e Abastecimento. Instrução Normativa $n^{\circ} 46$, de 23 de outubro de 2007. Adota o regulamento técnico de identidade e qualidade de leites fermentados. Diário Oficial da União, 24 out. 2007. Seção 1, p.4.

BRASIL. Ministério da Agricultura, Pecuária e Abastecimento. Instrução Normativa $n^{\circ} 62$, de 29 de dezembro de 2011. Aprova o Regulamento Técnico de Produção, Identidade e Qualidade do Leite Tipo A, o Regulamento Técnico de Identidade e Qualidade de Leite Cru Refrigerado, o Regulamento Técnico de Identidade e Qualidade de Leite Pasteurizado e o Regulamento Técnico da Coleta de Leite Cru Refrigerado e seu Transporte a Granel. Diário Oficial da União, 30 dez. 2011. Seção 1, p.6-11.

ÇAKMAKÇI, S.; ÇETIN, B.; TURGUT, T.; GÜRSES, M.; ERDOĞAN, A. Probiotic properties, sensory qualities, and storage stability of probiotic banana yogurts. Turkish Journal of Veterinary Animal Science, v.36, p.231-237, 2012. DOI: 10.3906/ vet-1007-2.

DECIMO, M.; MORANDI, S.; SILVETTI, T.; BRASCA, M. Characterization of gram-negative psychrotrophic bacteria isolated from Italian bulk tank milk. Journal of Food Science, v.79, p.M2081-M2090, 2014. DOI: 10.1111/1750-3841.12645.

DREZNER, Z.; TUREL, O.; ZEROM, D. A modified Kolmogorov-Smirnov test for normality. Communications in Statistics - Simulation and Computation, v.39, p.693-704, 2010. DOI: $10.1080 / 03610911003615816$.

EUROPEAN COMISSION. Regulation EC n ${ }^{\circ} 853 / 2004$ of the European Parliament and of the Council of April 29 2004. Laying down specific hygiene rules for food of animal origin. Official Journal of the European Union, L139/55, 30. Apr. 2004.

GRADE "A" pasteurized milk ordinance. Washington: U.S. Department of Health and Human Services, Public Health Service, Food and Drug Administration, 2011.

HUANG, C.B.; GEORGE, B.; EBERSOLE, J.L. Antimicrobial activity of n-6, n-7 and n-9 fatty acids and their esters for oral microorganisms. Archives of Oral Biology, v.55, p.555-560, 2010. DOI: 10.1016/j.archoralbio.2010.05.009.

KANKAANPÄÄ, P.E.; SALMINEN, S.J.; ISOLAURI, E.; LEE, Y.K. The influence of polyunsaturated fatty acids on probiotic growth and adhesion. FEMS Microbiology Letters, v.194, p.149153, 2001. DOI: 10.1016/S0378-1097(00)00519-X.

LECOMTE, X.; GAGNAIRE, V.; LORTAL, S.; DARY, A.; GENAY, M. Streptococcus thermophilus, an emerging and promising tool for heterologous expression: advantages and future trends. Food Microbiology, v.53, p.2-9, 2016. DOI: 10.1016/j. fm.2015.05.003.

LEITNER, G.; SILANIKOVE, N.; JACOBI, S.; WEISBLIT, L.; BERNSTEIN, S.; MERIN, U. The influence of storage on the farm and in dairy silos on milk quality for cheese production. International Dairy Journal, v.18, p.109-113, 2008. DOI: 10.1016/j.idairyj.2007.09.001.

LOPEZ, C.; MADEC, M.-N.; JIMENEZ-FLORES, R. Lipid rafts in the bovine milk fat globule membrane revealed by the lateral segregation of phospholipids and heterogeneous distribution of glycoproteins. Food Chemistry, v.120, p.22-33, 2010. DOI: 10.1016/j.foodchem.2009.09.065.

MALACARNE, M.; SUMMER, A.; FRANCESCHI, P.; FORMAGGIONI, P.; PECORARI, M.; PANARI, G.; VECCHIA, P.; SANDRI, S.; FOSSA, E.; SCOTTI, C.; MARIANI, P. Effects of storage conditions on physico-chemical characteristics, salt equilibria, processing properties and microbial development of raw milk. International Dairy Journal, v.29, p.36-41, 2013. DOI: 10.1016/j.idairyj.2012.10.005.

MANKAI, M.; BOULARES, M.; MOUSSA, O.F.; KAROUI, R.; HASSOUNA, M. The effect of refrigerated storage of raw milk 
on the physicochemical and microbiological quality of Tunisian semihard Gouda-type cheese during ripening. International Journal of Dairy Technology, v.65, p.250-259, 2012. DOI: 10.1111/j.1471-0307.2012.00822.x.

NÖRNBERG, M.F.B.L.; FRIEDRICH, R.S.; WEISS, R.D.N.; TONDO, E.C.; BRANDELLI, A. Proteolytic activity among psychrotrophic bacteria isolated from refrigerated raw milk. International Journal of Dairy Technology, v.63, p.41-46, 2010. DOI: 10.1111/j.1471-0307.2009.00542.x.

O'CONNELL, A.; RUEGG, P.L.; JORDAN, K.; O'BRIEN, B.; GLEESON, D. The effect of storage temperature and duration on the microbial quality of bulk tank milk. Journal of Dairy Science, v.99, p.3367-3374, 2016. DOI: 10.3168/jds.2015-10495.

OLIVEIRA, R.P.S.; FLORENCE, A.C.R.; SILVA, R.C.; PEREGO, P.; CONVERTI, A.; GIOIELLI, L.A.; OLIVEIRA, M.N. Effect of different prebiotics on the fermentation kinetics, probiotic survival and fatty acids profiles in nonfat symbiotic fermented milk. International Journal of Food Microbiology, v.128, p.467-472, 2009. DOI: 10.1016/j.ijfoodmicro.2008.10.012.

PERIN, L.M.; MORAES, P.M.; ALMEIDA, M.V.; NERO, L.A. Interference of storage temperatures in the development of mesophilic, psychrotrophic, lipolytic and proteolytic microbiota of raw milk. Semina: Ciências Agrárias, v.33, p.333-342, 2012. DOI: $10.5433 / 1679-0359.2012 v 33 n 1 p 333$.

RAJAPAKSHA, D.S.W.; KODITHUWAKKU, K.A.H.T.; SILVA, K.F.S.T.; RUPASINGHE, R.A.J.N.L. Evaluation of potassium sorbate and E-polylysine for their inhibitory activity on post-acidification of set yoghurt under cold storage for 20 days. International Journal of Scientific and Research Publications, v.3, p.81-87, 2013.

SCATAMBURLO, T.M.; YAMAZI, A.K.; CAVICCHIOLI, V.Q.; PIERI, F.A.; NERO, L.A. Spoilage potential of Pseudomonas species isolated from goat milk. Journal of Dairy Science, v.98, p.759-764, 2015. DOI: $10.3168 /$ jds.2014-8747.
SETTACHAIMONGKON, S.; VALENBERG, H.J.F. van; GAZI, I.; NOUT, M.J.R.; HOOIJDONK, T.C.M. van; ZWIETERING, M.H.; SMID, E.J. Influence of Lactobacillus plantarum WCFS1 on post-acidification, metabolite formation and survival of starter bacteria in set-yoghurt. Food Microbiology, v.59, p.14-22, 2016. DOI: 10.1016/j.fm.2016.04.008.

SHIN, Y.K.; OH, N.S.; LEE, H.A.; LEE, H.A.; CHOI, J.-W.; NAM, M.S. Effects of psychrotrophic bacteria, Serratia liquefaciens and Acinetobacter genomospecies 10 on yogurt quality. Korean Journal for Food Science of Animal Resources, v.34, p.543-551, 2014. DOI: $10.5851 /$ kosfa.2014.34.4.543.

SINCLAIR, C.G.; CANTERO, D. Fermentation modeling. In: MCNEIL, B.; HARVEY, L.M. (Ed.). Fermentation: a practical approach. Oxford: Oxford University, 1990. p.65-112.

SOUZA, V.; NADER FILHO, A.; FERREIRA, L.M.; CERESER, N.D. Características microbiológicas de amostras de leite de tanque comunitário. Arquivo Brasileiro de Medicina Veterinária e Zootecnia, v.61, p.758-761, 2009. DOI: 10.1590/ S0102-09352009000300035.

STOECKEL, M.; LIDOLT, M.; ACHBERGER, V.; GLÜCK, C.; KREWINKEL, M.; STRESSLER, T.; NEUBECKC, M. von; WENNINGC, M.; SCHERERC, S.; FISCHERB, L.; HINRICHS, J. Growth of Pseudomonas weihenstephanensis, Pseudomonas proteolytica and Pseudomonas sp. in raw milk: impact of residual heat-stable enzyme activity on stability of UHT milk during shelf-life. International Dairy Journal, v.59, p.20-28, 2016. DOI: 10.1016/j.idairyj.2016.02.045.

YAMAZI, A.K.; MOREIRA, T.S.; CAVICCHIOLI, V.Q.; BURIN, R.C.K.; NERO, L.A. Long cold storage influences the microbiological quality of raw goat milk. Small Ruminant Research, v.113, p.205-210, 2013. DOI: 10.1016/j. smallrumres.2013.02.004.

WEHR, H.M.; FRANK, J.F. (Ed.). Standard methods for the examination of dairy products. $17^{\text {th }}$ ed. Washington: American Public Health Association, 2004.

Received on May 24, 2016 and accepted on August 18, 2016

Pesq. agropec. bras., Brasília, v.52, n.2, p.104-112, fev. 2017

DOI: 10.1590/S0100-204X2017000200004 